\title{
On the myth of the Edwin Smith papyrus: is it magic or science?
}

\author{
Alexander Brawanski \\ Received: 1 October 2012 / Accepted: 3 October 2012 /Published online: 17 October 2012 \\ (C) Springer-Verlag Wien 2012
}

\section{Introduction}

The Edwin Smith papyrus (ESP) [1] holds a very special position in the canon of the ten surviving major medical papyri from ancient Egypt. The text has a clear, logical structure. It describes injuries and wounds from head to toe (a capite ad calcem), separated into 48 cases. Again, each case is presented in a clearly structured manner. After the title, the diagnostic procedure and relevant clinical signs are enumerated. When deemed necessary, differential diagnostics are mentioned as well as an additional explanation of some of the clinical symptoms and specific medical terms. A verdict follows that comprises three treatment possibilities: either the disease can be treated, or it is a disease "the physician will fight with," or nothing can be done for the patient. Depending on this, treatment options are given.

After the editio princeps (Fig. 1) by Breasted in 1930 [2] and the standard edition of the hieroglyphic text in 1959 [3], three more recent major editions of this papyrus in translation with commentary have been published $[1,4,5]$, in addition to some articles that studied single cases [6-11]. Most of these publications were more or less philogically oriented. Consequently, since its publication the ESP has attracted modern physicians, who have explained the injuries based on their knowledge of modern medicine and tried to evaluate the efficacy of the proposed treatments from a modern medical point of view [12-14]. Many of these students praised the ESP as the first scientific work of medicine because of its clearly structured layout and the lack of magical practice $[15,16]$. Unfortunately, often it is not mentioned or missed that the ESP also contains prescriptions with magical spells or allusions. This holds true for cases 8 and 9 in the surgical part and

A. Brawanski $(\bowtie)$

Clinic of Neurosurgery, University of Regensburg,

Franz-Josef-Strauss Allee 11,

93042 Regensburg, Germany

e-mail: alexander.brawanski@klinik.uni-regensburg.de several magical spells on the verso of the last page, which are not directly related to the surgical treatise. These, of course, do not fit the pure scientific approach. When mentioned, the magic interludes in this papyrus were often defined as unnecessary slips of the otherwise scientific approach and were mostly discarded as a "fall back" to more pagan times [17], which allegedly happened to ancient Egyptian medicine in the course of its later development [18].

The aim of this article is to define the socio-cultural environment ("Sitz im Leben") of this document in order to explain this putative contradiction. Furthermore, its "scientific character" will be discussed. In detail, the following issues will be addressed: What was the social organization of ancient Egypt at the time of the ESP (1600 BCE)? How does medicine fit into this, and how was it executed practically? What are the treatment concepts and how does magic fit into all this? How did the individual patient fare? This article will not discuss the ESP on a case-by-case basis, but tries to give an overview.

\section{The social-governmental organization}

Around $1600 \mathrm{BCE}$, the approximate time the ESP was writen, although it quite obviously is a copy of a much older papyrus, ancient Egypt was a highly organized society [19]. The ancient Egyptian society included professional specializations. One finds carpenters, fishermen, peasants, and various craftsmen, just to name a few. This facilitated the great building projects and enterprises of the state such as temples and pyramids. Specialization, which had started many centuries before, necessitated a good working administration, as a carpenter had to be supplied with food that he could not generate for himself. Therefore, nearly every transaction related to the distribution of goods, food, and the work force was managed by the state and registered in archives to keep things running well. In general, this form of governmental organization (redistributive economy [20]) 
Fig. 1 Photographs of the Edwin Smith papyrus from the original publication by Breasted [57]. a Part of a page of the original in hieratic; $\mathbf{b}$ the modern scientific transcription into hieroglyphics

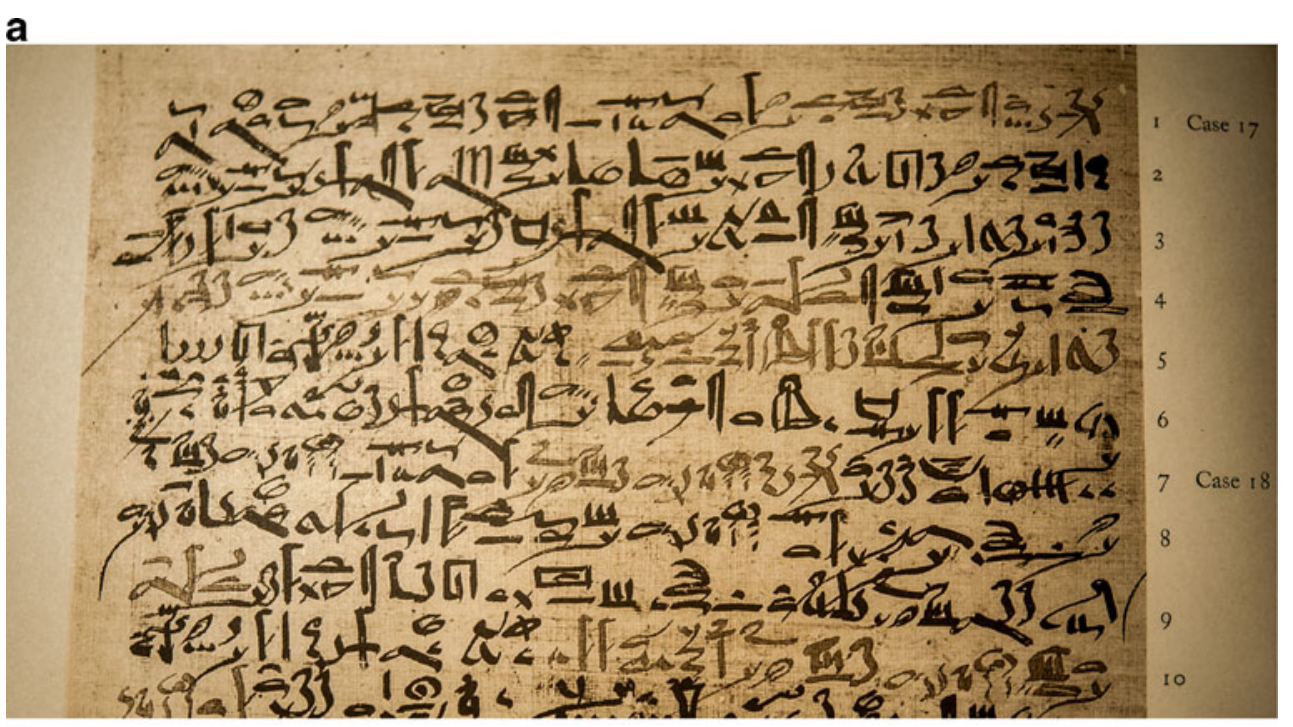

b

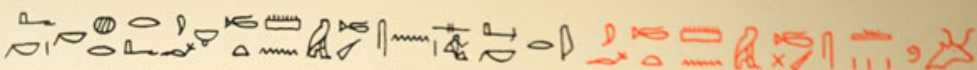

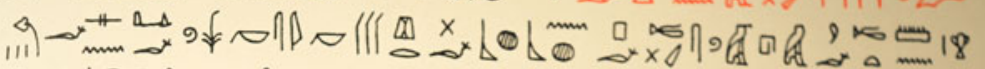

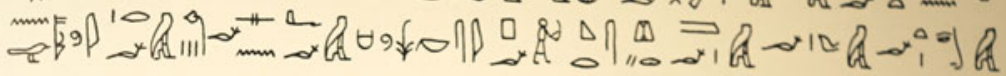

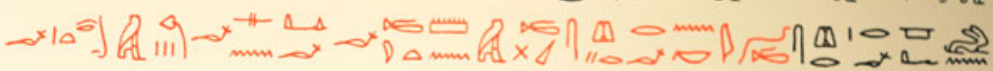

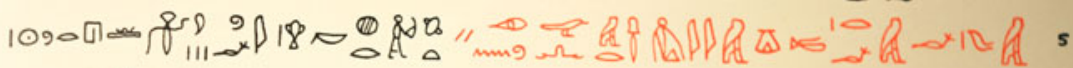

$$
\begin{aligned}
& \text { б 耑 } \\
& \text { सब ब्व } \\
& \text { g) m }
\end{aligned}
$$

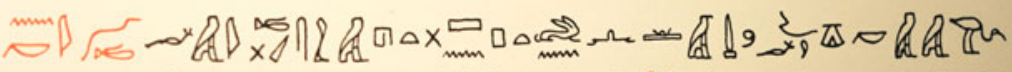

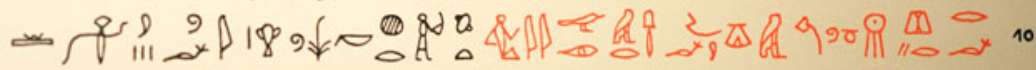

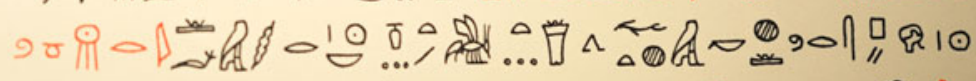

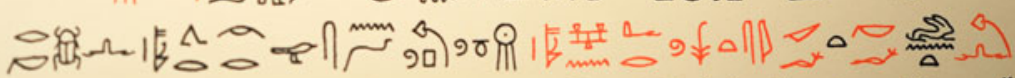

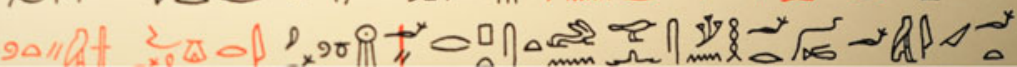

represents the concept of the division of and specialization in labor and the redistribution of "surplus food," which constitutes one hallmark of all ancient civilizations [21].

Most of the administrative archives were located in respective centers connected to temples. The relevant location was a building called the "House of Life" [22]. The Egyptian countryside was covered by a more or less tight net of temples (and adjoining administrative buildings). These institutions housed the standard documents, which constituted the intellectual basis of the Egyptian state itself. These documents included royal decrees and religious texts in addition to administrative documents. In addition, these places kept written documents for issues dealing with the necessities of daily life. Astronomical observational lists for defining the rise of the Nile, mathematical (engineering) papyri for building projects and land surveys after the annual flood, and of course medical papyri belonged to this knowledge base. These documents were used for reference and for the education of scribes and governmental employees, which took place in the temple precincts as well. In addition, the major (temple) centers had to organize religious feasts, expeditions, and building enterprises in accordance with the royal court. Also jurisdiction was practiced there. However, it is necessary to understand that these administrative centers were not exclusively responsible for the welfare of the state by wringing taxes out of the peasants and ordering corvèe work, as one might be led to believe. On the contrary, these institutions also had to supply 
services and help for the common people in order to keep the state running. This fact is mirrored in the various "teachings," presenting guidelines for administrative personnel on how to behave in specific situations [23]. Egyptology has proved several periods in the 4,000 years of ancient Egyptian history in which this centralized system broke down and social turmoil occurred.

\section{The place of medicine in society and its practical execution}

On the very practical side, we can differentiate a governmental medicine from a "folk medicine." Common people may have asked somebody from their village, the neighbors, or a lay person with some medical knowledge, for help with minor diseases and illnesses. A text from love songs of the New Kingdom describes how this could have happened: "I will lie down at home and do as if I were sick; the neighbors will come and look after me..." [24]. In more serious situations, common patients would have sought help from a "professional" in the temple and thus addressed governmentally organized support. Usually medical doctors would not have gone to people in the countryside, although exceptions certainly occurred [25]. In the temple environments, the patients were attended by physicians, assessed and treated, and possibly told to come back. It seems likely that they could stay there for treatment and medical observation, but this is not described prior to Hellenistic times [26]. The story of the Wesir Wesh-Ptah relates a description of how things could have been handled in such a context: "After observation of the patient all the relevant scriptures were brought in order to get a clue what had happened to him. Then treatment was advised accordingly" [25].

Different scenarios can be projected for the royal entourage and high-ranking officials. Several physicians were permanently present at the royal court, as specific titles suggest [25]. But otherwise the procedure per se was the same: After examination of the patient and checking the documents, treatment was done.

Clearly, the therapeutic goal of the ancient Egyptian physician was to cure the patient and return him to health as much as possible. However, this should not be seen so simply. The intent to treat had farther-reaching motives. Besides the individual fate of a single patient, there was a general interest of the state in the widest sense to keep its population healthy and functional. Consequently, the medical profession in ancient Egypt had a structured organization. We find masters, inspectors, and chiefs of physicians [25]. Furthermore, physicians were appointed to specific jobs that necessitated their permanent presence for a limited time, such as service during an expedition, at a major construction site, or during a journey by ship [25, 27]. All this can be adduced as evidence for this interest, albeit there is some Egyptological discussion about the real meaning and efficacy of all these titles [25]. The state understood that a healthy population was a prerequisite for a functioning state. Again, this must not be understood as a generous attitude of the government. On the contrary, the "lower ranks" of the population expected care and provisions through an orderly setup of society with all its supplies and thus accepted the social inequality that necessarily existed in those societies [28]. This is mirrored in part in the so-called "lamentation literature" in which the misadventures of a non-functioning state are described and the missing "order of the world" (see below) is lamented. In "The Lamentations of Ipuwer," the Pharaoh as the major representative of this order is obviously reproached for not fulfilling his duties in this respect [29]. One major aspect of the governmental medical care was simply to keep the "system" running.

Considering the above circumstances, we can explain the different types of medical documents that survived, albeit we have to be clear that we have something like $0.001 \%$ of the actually existing ancient Egyptian medical literature. Out of the canonical scripts, excerpts were made for specific situations - often by scribes who did not always understand what they had to write-and passed to the physicians appointed to a specific task. So one can imagine that more information on traumatic incidences was needed for building enterprises, whereas expeditions needed more information about what we moderns would call infections and the consequences of malnourishment, skin problems (sun burn, parasites, snake and scorpion bites), and eye diseases. Many of the preserved abbreviated medical manuals may have originated in such situations. Some of the larger medical papyri found in tombs, like the ones in the collections of the Ramesseum [30] and the Chester Beatty papyri [31], could have been given as a gift after the successful completion of a difficult job for which the specific copy was prepared. There also were copies made for personal use. Papyrus libraries were bequeathed within families to keep the profession there [32]. These papyri were very valuable as they represented knowledge that was otherwise not available.

\section{Treatment concepts, magic, and science}

The ancient physicians had a specific and rather sophisticated pathophysiological concept of (internal) diseases [33], which unfortunately complies with little of the actual inner workings of the body as we understand them today. They assumed some type of circulatory system, which included the heart and in which bad substances could accumulate and circulate. Furthermore, an elaborated materia medica was available with sophisticated application methods. Some of 
the applied drugs were effective [34-36]. This knowledge was acquired over the centuries by trial and error and finally led to the high esteem of the medical profession in the ancient world [37]. Part of this knowledge has survived in several larger medical papyri and many fragments [18], a textual corpus of which the ESP constitutes only a minor fraction.

As has often been observed by students, the anatomical descriptions in the ESP are clear, descriptive, and sometimes unique. One of the classics is the comparison of the surface of the (injured) brain to molten copper (case 6). However, the general anatomical knowledge was limited; sometimes it is nicknamed "kitchen" or slaughterhouse anatomy [38] because much of the information seems to be derived from the slaughterhouse indeed. An example is the uterus, which is represented hieroglyphically as the uterus bicornutus, which is not present in human beings. In this context, the question is unresolved as to whether at the time of the ESP the embalmers' knowledge was used by physicians and whether they were two strictly separated professions. According to Ghalioungui, there were individuals bearing the title of physician who very likely could have been embalmers as well [25]. In the later period of Egyptian history, the Egyptian title for physician could mean both. Some information that is presented in the ESP related to spinal injuries does suggest, however, that there must have been an exchange of information between these groups [7]. Otherwise, some descriptions of spinal injuries in the ESP could not be described in such detail.

Besides all this, the ancient Egyptian physicians firmly believed in supernatural forces such as demons, undead persons (Widergänger), and divine influences as causes of illnesses and consequently treated them by magicical rituals. The less obvious the cause of a disease, the more common was magic $[39,40]$ ! Magic and practical medicine were not different or contradictory to physicians. This differentiation is artificial and was introduced by modern medical historians [41]. The ancients often used magical spells to enhance the effectivity of medical applications, and often magic alone. Thus, there is a significant number of magical spells in other important medical papyri [42]. All this is not so necessary in the ESP, as the causes of the wounds and the injuries are well known, thus showing the "rational" approach, which exemplifies the strength of these ancient societies: The collection of information and facts and the classification of this information. This complies with the "organizational principle" that ruled these societies and without which they could not exist or survive. The ancient Egyptians had available lists of birds, countries, and even objects of daily life [43]. They used them for reference and education. The major intent of these lists was to classify and thus structure the world in order to cope with it. Knowledge meant power. Therefore, the knowledge of the physicians often was called "secret" and was not available to everyone, provided he could read at all.
This classification principle is perfectly exemplified in the ESP. The single cases are arranged from the top to bottom of the body. This may seem natural per se, but this structural principle again had a religious background. We know of litanies of Gliedervergottung (deification of members of the body) $[44,45]$ that have the same order. Here we come to another important point, namely that medicine was deeply rooted in the divine realm. The relevant documents were stored in the temples; education as well as treatment took place there. Some of the physicians may have been priests as well, and a specific type of priest also could magically treat patients [46] to some extent. All this explains why magic was a firm component of medical practice. Specifically in prescriptions with magic components, patients were often addressed as and equated with the god Horus, who was helped by his mother Isis.

In this context, we come to the major driving force of ancient Egyptian thought. All (official) activities had to follow one major principle that traverses all ancient Egyptian behavior: the universal order of the world-"Maat"which kept the world running. It had to be preserved by all means because it was threatened every day. This fact sets Egyptian medicine in the proper position and environment in this society. According to Egyptian belief, ancient "objects" with a long tradition underpinned the validity of this concept. Thus, we can find the statement in medical texts "that the text is a copy of an ancient papyrus found in a chest by chance" [47] and thus must be qualitatively good, because otherwise it would have perished. Ancient Egyptian society wanted stability and no abrupt changes. This can be seen very well in ancient Egyptian art, which did not change in its basic principles throughout the existence of ancient Egypt. Once a reasonable solution to a problem was achieved, it was preserved, and one did not necessarily look for other solutions. This complies well with the ESP, which was copied around $1600 \mathrm{BCE}$, but stems from a much older document according to the language of this papyrus [1].

This does not mean that there was no progress at all or that no variety of approaches existed. In the medical literature, there are significant variants in the selection and applications of drugs [40]. Even foreign treatments were accepted in the medical canon [42, 48, 49]. However, over time there was little obvious significant change. Due to this general attitude of ancient Egyptian society and due to the close connection of medicine to the divine, science in the modern sense was not possible and possibly not even thought of. One did not experiment with religious issues and endanger the general world order. The ancient Greeks were the first to question the divine influence on diseases in the seventh century BCE. Obviously this society was open to these questions [50]. However, even at the time when Hippocrates was active, the Asclepiads still recommended treatment in the temples and help from the gods [51]. 


\section{The individual patient}

Now the fate of the individual patient should be examined in reference to the cases described in the ESP.

One of the major issues seems to have been to establish a proper prognosis that determined the further procedures. This may sound astonishing at first. However, it is understandable when we regard this from the viewpoint of a major organization. This was nothing other than triage, which makes even more sense in the context of limited treatment options (see below). The verdict/prognosis was written in red in the ESP, which underlines its importance. This method is not unusual as we can still find this approach in ancient Greek medicine (1,000 years later). Here the major issue was also determining the prognosis [52]. Actually, the authority and credibility of an ancient Greek physician depended to a large extent on establishing a fast and proper prognosis [53].

It is important to note that the Egyptian physicians did not give a single disease name in the ESP, but an enumeration of symptoms. This is a relevant fact, as a "singleword" diagnosis usually implies a coherent pathophysiological concept that each physician understands. Thus, for modern physicians the concept of diabetes includes various aspects that do not have to be enumerated each time. However, a loose collection of symptoms rather constitutes a syndrome, in the best medical sense, which does not necessarily imply an understanding of the underlying pathophysiology. We would for instance summarize some of the injuries in the ESP (e.g., cases 18-20) as cranial base fractures. To any modern physician, this term would mean a specific injury with variable severity depending on the location and strength of the impact. Thus, a physician would rather summarize the single cases under one heading. Similarly, the last case (case 48) in the ESP deals with lower back pain. Several symptoms are enumerated. From a modern point of view, this could indicate several diagnoses, such as a tumor, a slipped disc, or a simple joint problem. The ancient Egyptian physician gave a "syndromatic" description from which a final modern diagnosis can hardly be developed, as relevant information is missing. Thus, often a definitive modern diagnosis cannot be made simply because of the lack of specific information in the ESP. This is not a denigration of the ancient Egyptian medical art, which was quite sophisticated despite their limited knowledge, but we have to know what we can take for granted.

In addition, we have to be clear that the treatment options in the ESP are very limited. Most of them are supportive in the best sense, but hardly any of them are curative. One exception may be the readjustment of a dislocated jaw (case 25). The same holds true to some extent for the relocation of a broken collarbone (cases 34-35). Here, the outer contour is readjusted; however, the fracture is still there with all its implications for malfunctioning of the adjacent joint (shoulder). Besides this, some treatment suggestions are clearly detrimental to the patient. In case 28 , an injury of the esophagus is obviously described. The physician recommended a closure of the superficial wound without further inspection of the deeper layers of the injury. This patient would definitely die from the sequelae of a mediastinitis, which is still a severe disease today. One may muse about the fact that the physician recommended a superficial closure of the wound in this case. Clearly the outflow of water should be mended. The guiding principle was obviously the restoration of the integrity of the outer aspects of the body. This corresponds well to the practice of mummification. Again the outer appearance of the mummy was important for the afterlife, but not so much the internal organs, which were removed during mummification and put in canopic jars separately.

Thus, the fate of the patient was actually determined by the seriousness of the injury, the severity of the following infection, and the physical strength of the patient to cope with these. The main intent of the ancient Egyptian physician was to establish a prognosis. We must be clear about the fact that a negative prognosis meant that the patient was left alone. What this may have looked like is described more fully in the Hippocratic Epidemics. I quote Epidemics 7,32 in reference to the ESP, case 22: "On a Macedonian: ...he was struck over the left temple, a superficial wound. He fainted after the hit and fell. On the third day he was speechless. He tossed about. Fever was not very intense.... He heard nothing and was not conscious, nor was he still. Moisture was around his forehead and beneath the nose to the chin. He died on the fifth day" [54]. It is interesting to note that these observations, which are of importance to the physician, are not mentioned in the ESP. This is simply due to the fact that "bad" things could and should not be written down. The Egyptians believed in the supernatural strength of their script; it was not understood as a mere transporter of information. Describing bad events would disturb Maat, the general word order.

\section{Conclusion}

What is the best way to approach the ESP? It is rooted in a complex environment, which has to be taken into account in order to appreciate this document fully. Magic definitely was an elementary part of ancient Egyptian medical practice and was applied at various occasions. This approach to cope with problems does not limit the overall achievements of this ancient society. Does the ESP contain science? That depends on the definition and is difficult to grasp [55]. If one applies the "modern" idea of science representing the objective truth, the answer would be no. However, respecting the specific principles to define natural events and mechanisms, which 
each of these ancient societies used, I would say - in a basic sense-_yes." However, a simple "close reading" of the ESP, including one to apply modern concepts and diagnoses [56], will most likely not do justice to this unique document.

Acknowledgments I want to thank H.-J.Thissen, H.-W. FischerElfert, K.M. Schebesch, and M. Proescholdt for helpful comments and suggestions. All remaining errors are mine.

Conflicts of interest None

\section{References}

1. Allen JP, Metropolitan Museum of Art (New York, NY) (2005) The art of medicine in ancient Egypt. Metropolitan Museum of Art New York

2. Breasted JH, New-York Historical Society L (1930) The Edwin Smith surgical papyrus. The University of Chicago Press, Chicago

3. Grapow H (1958) Die medizinischen Texte in hieroglyphischer Umschreibung autographiert. Akademie-Verlag, Berlin

4. Bardinet T (1995) Les papyrus médicaux de l'Égypte pharaonique: traduction intégrale et commentaire. Fayard, Paris

5. Westendorf W (1966) Papyrus Edwin Smith, ein medizinisches Lehrbuch aus dem alten Ägypte: Wund- und Unfallchirurgie, Zaubersprüche gegen Seuchen, verschiedene Rezepte. H. Huber, Bern

6. Brawanski A (2001) Die Fälle 1-8 des Papyrus Edwin Smith ("Schädelhirntraumafälle"). Stud Altägyptischen Kult 29:7-39

7. Brawanski A (2004) Die Wirbelsäulenverletzungen des Papyrus Edwin Smith (Fall 29-33). Stud Altägyptischen Kult 32:59-80

8. Brawanski A (2006) Mittelgesichtsverletzungen im Papyrus Smith. Stud Altägyptischen Kult 35:43-60

9. Goldwyn RM (1982) Is there plastic surgery in the Edwin Smith Papyrus? Plast Reconstr Surg 70:263-264

10. Hughes JT (1988) The Edwin Smith surgical papyrus: an analysis of the first case reports of spinal cord injuries. Paraplegia 26:71-82

11. Kamp MA, Tahsim-Oglou Y, Steiger HJ, Hanggi D (2012) Traumatic brain injuries in the ancient Egypt: insights from the Edwin Smith Papyrus. J Neurol Surg A Cent Eur Neurosurg 73:230-237

12. Sanchez GM, Burridge AL (2007) Decision making in head injury management in the Edwin Smith Papyrus. Neurosurg Focus 23:1-9

13. Smith L (2011) The Kahun Gynaecological Papyrus: ancient Egyptian medicine. J Fam Plan Reprod Health Care 37:54-55

14. van Middendorp JJ, Sanchez GM, Burridge AL (2010) The Edwin Smith papyrus: a clinical reappraisal of the oldest known document on spinal injuries. Eur Spine J 19:1815-1823

15. Gordetsky J, O'Brien J (2009) Urology and the scientific method in ancient Egypt. Urology 73:476-479

16. Jungraithmayr W, Weder W (2012) Chest surgical disorders in ancient Egypt: evidence of advanced knowledge. Ann Surg 255:605-608

17. Westendorf W (1992) Erwachen der Heilkunst. Die Medizin im Alten Ägypten. Artemis \& Winkler, Zürich-[München]

18. Nunn JF (1996) Ancient Egyptian medicine. Trans Med Soc Lond 113:57-68

19. Kemp BJ (1989) Ancient Egypt. Anatomy of a Civilization. Routledge London and New York

20. Helck W, Westendorf W (1986) Lexikon der Ägyptologie VI: Stele-Zypresse. Otto Harrassowitz, Wiesbaden

21. Trigger BG (1993) Early civilizations. Ancient Egypt in context. The American University in Cairo Press, Cairo
22. Helck W, Westendorf W (1980) Lexikon der Ägyptologie III: Horhekenu-Megeb. Otto Harrassowitz, Wiesbaden

23. Simpson WK (1973) The literature of Ancient Egypt. An anthology of stories, instructions and poetry. New Edition. With Translations by R.O. Faulkner, Edward F. Wente, Jr., William Kelly Simpson. Yale University Press New Haven and London

24. Mathieu B (1996) La poésie amoureuse de l'Égypte ancienne. Recherches sur un genre littéraire au Nouvel Empire. Institut français d'archéologie orientale, Le Caire

25. Ghalioungui P (1983) The physicians of pharaonic Egypt. Zabern Deutsches Archäologisches Institut, Abteilung Kairo

26. Philips AK (1989) Observations on the Alleged New Kingdom Sanatorium at Deir el-Bahari. Göttinger Miszellen 89:77-85

27. Engelmann H, Hallof J (1995) Zur medizinischen Nothilfe und Unfallversorgung auf staatlichen Arbeitsplätzen im alten Ägypten. Z ägyptische Sprache und Altertumskunde 122:104-137

28. Lull V, Mico R (2011) Archaeology of the origin of the state. Oxford University Press, Oxford

29. Enmarch R (2008) A world upturned: commentary on and analysis of the dialogue of Ipuwer and the Lord of All. Oxford University Press, Oxford

30. Gardiner AH (1955) The Ramesseum papyri: plates. Oxford University Press for the Griffith Institute, Oxford

31. Gardiner AH (1935) Hieratic papyri in the British Museum: third series: Chester Beatty gift. British Museum, London

32. Pestman PW (1982) Who were the owners, in the "community of workmen", of the Chester Beatty Papyri. In: Demarée RJ, Janssen JJ (eds) Gleanings from Deir el-Medîna. Nederlands Inst. voor het Nabije Oosten, Leiden, pp 155-172

33. Nunn JF (1996) Ancient Egyptian medicine. University of Oklahoma Press, Norman

34. Germer R (1993) Ancient Egyptian pharmaceutical plants and the Eastern Mediterranean. Brill, Leiden

35. Hofmann T (2008) Honig als "Specificum": pEdwin Smith und die moderne Medizin. Ein Ausflug in den Cyberspace und eine Bibliographie. Z ägyptische Sprache und Altertumskunde 135 (135): 140-149

36. Manniche L (1989) An ancient Egyptian herbal. British Museum

37. Murray AT, Dimock GE (1995) The Odyssey. Harvard University Press, Cambridge

38. Dawson WR (1929) Magician and leech : a study in the beginnings of medicine with special reference to ancient Egypt. Methuen London

39. Leitz C (2002) Rabenblut und Schildkrötengalle: Zum vermeintlichen Gegensatz zwischen magisch-religiöser und empirischrationaler Medizin. In: Karenberg A, Leitz C (eds) Heilkunde und Hochkultur II Lit. Verlag, Münster, pp 49-73

40. Ritner RK (2000) Innovations and adaptations in ancient Egyptian medicine. J Near East Stud 59:107-117

41. Sigerist HE (1955) A history of medicine. Volume I: primitive and archaic medicine. Oxford University Press, New York

42. Westendorf W (1999) Handbuch der altägyptischen Medizin. Brill, Leiden

43. Gardiner AH Ancient Egyptian Onomastica. [S.1.]: OUP, 1947 (1968)

44. Helck W, Westendorf W (1977) Lexikon der Ägyptologie II: Erntefest-Hordjedef. Otto Harrassowitz, Wiesbaden

45. Quack JF (1995) Dekane und Gliedervergottung. Altägyptische Traditionen im Apokryphon Johannis. Jahrb Antike und Christentum 38:97-122

46. Halioua B, Ziskind B (2005) Medicine in the days of the pharaohs. Belknap Cambridge, MA; London

47. Grapow H (1955) Von den medizinischen Texten. Art, inhalt, sprache und stil der medizinischen Einzeltexte sowie Uberlieferung, Bestand und Analyse der medizinischen Papyri. AkademieVerlag, Berlin 
48. Fischer-Elfert H-W (2011) Sāmānu on the Nile: the transfer of a Near Eastern demon and magico-medical concept into New Kingdom Egypt. In: Collier M, Snape S (eds) Ramesside studies in honour of K.A. Kitchen. Rutherford, Bolton, pp 189-198

49. Leitz CPD, The British Museum (1999) Magical and medical papyri of the New Kingdom. British Museum Press for the Trustees of the British Museum, London

50. Huff TE (2011) Intellectual curiosity and the scientific revolution: a global perspective. Cambridge University Press, Cambridge

51. Lloyd GER (2003) In the grip of disease. Oxford University Press, Oxford

52. Nutton V (2005) Ancient medicine. Routledge, London
53. Graumann LA (2000) Die Krankengeschichten der Epidemienbücher des Corpus Hippocraticum. Shaker Verlag, Aachen

54. Smith W (1994) Hippocrates VII. Harvard University Press, Cambridge

55. Rossi C (2010) Science and technology: pharanonic. In: Lloyd AB (ed) A companion to ancient Egypt vol 1. Wiley-Blackwell, Oxford, p 391

56. Jouanna J (1996) Die Entstehung der Heilkunst im Westen In: M.G. (ed) Die Geschichte des medizinischen Denkens C.H. Beck München, pp 28-80

57. Breasted JH, Smith E, University of Chicago. Oriental I, NewYork Historical Society L (1930) The Edwin Smith surgical papyrus. University of Chicago Press, Chicago 